\title{
A Small Yes for Presidentialism: The Turkish Constitutional Referendum of April 2017
}

\section{Berk Esen \& Şebnem Gümüşçü}

To cite this article: Berk Esen \& Șebnem Gümüșçü (2017) A Small Yes for Presidentialism: The Turkish Constitutional Referendum of April 2017, South European Society and Politics, 22:3, 303-326, DOI: 10.1080/13608746.2017.1384341

To link to this article: https://doi.org/10.1080/13608746.2017.1384341

曲 Published online: 11 Oct 2017.

Submit your article to this journal

III Article views: 1513

View Crossmark data $[\pi$

Citing articles: 4 View citing articles 주 


\title{
A Small Yes for Presidentialism: The Turkish Constitutional Referendum of April 2017
}

\author{
Berk Esen and Şebnem Gümüşçü
}

\begin{abstract}
Following four elections in three years, on 16 April 2017 Turkish voters once again went to the polls - this time under the emergency law established after the failed coup attempt of July 2016 - to vote on constitutional amendments aimed at replacing the existing parliamentary system with an executive presidency. This article reviews the content of the proposed constitutional amendments, analyses the campaign including the strategies employed by the main political actors in the'Yes' and 'No' camps and the resource advantages enjoyed by the ruling party, assesses the electoral performance of both sides through a summary of results from provincial areas and geographical regions, and considers how Turkish politics are likely to take shape under the new system.
\end{abstract}

\section{KEYWORDS}

Turkey; constitutional reform; executive presidency; competitive authoritarianism; Erdoğan. AKP; CHP

Following a series of elections - two parliamentary, one local, and one presidential —in three years, Turkish voters once again went to the polls on 16 April 2017 to give their verdict on a set of constitutional amendments that would replace the existing parliamentary system with an executive presidency. The 1982 Constitution had already been amended numerous times and these changes were put to popular vote on four other occasions (Kalaycıoglu 2012), two of which occurred under the AKP (Adalet ve Kalkınma Partisi - Justice and Development Party) that has ruled continuously since the 2002 general elections. President Recep Tayyip Erdoğan and the ruling AKP campaigned forcefully for the 'Yes' vote by taking advantage of the uneven playing field in relation to the opposition (OSCE 2017) which had also been the case during the June and November 2015 general elections (Esen \& Gümüşçü 2016; Sayarı 2016b). Meanwhile, the 'No' camp was composed of various political parties including the main opposition CHP (Cumhuriyet Halk Partisi - Republican People's Party) and pro-Kurdish HDP (Halkların Demokrasi Partisi - People's Democratic Party) together with groups of different ideological leanings. Despite the government's unfair advantages and an alliance with the MHP (Milliyetçi Hareket Partisi - National Action Party), the 'Yes' side prevailed by only a small margin (as shown in Table 1), denying Erdoğan the sweeping endorsement he had expected. Compared to their vote in the November 2015 elections, the parties supporting the 'Yes' camp incurred major losses in the 2017 referendum (see Table 2).

The 2017 referendum took place in the midst of an ongoing political crisis marked by several key developments. The most recent crisis started with the June 2015 elections when 
Table 1. Outcome of the Turkish constitutional referendum of April 2017.

\begin{tabular}{lc}
\hline & $\%$ \\
\hline YES & 51.4 \\
NO & 48.6 \\
Turnout & 85.4 \\
\hline
\end{tabular}

Table 2. The 2015 election results for the parties supporting the 'Yes' and 'No' camps in the April 2017 constitutional referendum.

\begin{tabular}{lccc}
\hline YES camp & AKP & MHP & AKP-MHP combined \\
\hline June 2015 & 40.9 & 16.3 & 57.2 \\
Nov 2015 & 49.5 & 11.9 & 61.4 \\
NO camp & & & \\
& CHP & HDP & CHP-HDP combined \\
June 2015 & 24.9 & 13.1 & 38.0 \\
Nov 2015 & 25.3 & 10.7 & 36.0 \\
\hline
\end{tabular}

Notes: The parties that did not pass the parliamentary threshold in these two elections received a total of 4.8 per cent of the vote in June 2015 and 2.7 per cent in November 2015. In the referendum the extra-parliamentary forces were divided between the 'Yes' and 'No' camps.

the AKP lost its parliamentary majority for the first time since coming to power in 2002(Öniş 2016; Kalaycıoglu 2017). In Summer 2015 the peace process with regard to the Kurdish insurgency came to an abrupt end, and the AKP called for snap elections in the midst of increasing violence in the country. In November 2015, the AKP recovered most of its electoral losses and regained its parliamentary majority, yet the party failed to restore stability. The AKP government increased its counter-insurgency measures, cracked down on academia, the media, and civil society, and President Erdoğan replaced the then Prime Minister Davutoğlu with the more loyal Binali Yıldırım. In July 2016 the political crisis took a new turn when a junta within the Turkish military attempted to unseat Erdoğan and the AKP government (Esen \& Gümüşçü 2017), killing 250 civilians and injuring hundreds. The AKP government, thanks to its parliamentary majority, declared a state of emergency in July 2016, and President Erdoğan exerted his control over the cabinet as de facto head of the state and the executive and started to rule by decrees without much parliamentary oversight. These decrees led to the sacking of tens of thousands of civil servants and teachers, the appointment of trustees to firms of various sizes, purges in academia, as well as the closure of several civil society associations and media outlets, as the government carried out mass arrests of civil servants, journalists, and opposition leaders.

The referendum was thus held in a context in which the state of emergency allowed provincial governors and security forces to restrict freedom of speech, movement, and assembly. As such, the campaign period confirmed the findings of recent studies on democratic breakdown in Turkey (Somer 2016, Esen \& Gümüşçü 2016) and further indicated the consolidation of the rising competitive authoritarian regime in its stead (Esen \& Gümüşçü 2016, Özbudun 2015, Sayarı 2016a). Attesting to this fact, the AKP ran a one-sided campaign aided by the state apparatus that dominated the media and public space.

However, the broad nature of the 'No' camp helped the government's critics to overcome, at least partly, these enormous resource advantages enjoyed by the ruling party. For the first time during its rule, the AKP was confronted by a large coalition of parties and groups that had little in common, both in terms of policy agendas and ideological backgrounds. Except 
for the MHP and two minor extra-parliamentary parties, all the opposition parties rejected the proposed amendments. The opposition used a similar framing to oppose the proposed constitutional amendments, accusing Erdoğan of aiming to establish one-man rule. The ideologically heterogeneous nature of the 'No' camp disabled the AKP government's attempts to criminalise its critics and benefit from political polarisation. ${ }^{1}$ The results indicate that half of the electorate consolidated against the executive presidency, an ominous sign for President Erdoğan. Moreover, the government's victory was disputed due to serious allegations of electoral fraud that, given the close margin, may have swayed the outcome of the referendum. The decision of the YSK (Yüksek Seçim Kurulu - High Election Council) to count ballots without an official stamp ex post facto caused a major stir in the'No' camp. The serious charges of electoral fraud also compromised the integrity of future elections.

This article provides an analysis of the 2017 referendum and its long-term implications for Turkish politics. It will first review the content of the proposed constitutional amendments. The article will then analyse the campaign period to review the different strategies employed by the main political actors in the 'Yes' and 'No' camps. In this section, the focus will be on the resource advantages enjoyed by the ruling party and the uneven playing field in Turkish politics. The following section will assess the electoral performances of both sides through a summary of results from provincial areas and geographical regions. The final section concludes with a discussion on how Turkish politics are likely to shape up under the new system.

\section{Why constitutional change?}

Indeed, the political elite in Turkey had long reached a consensus on the necessity of replacing the existing Constitution penned by the military junta in 1982 with a civil and democratic alternative. With this aim, after the 2011 general election, the four parties represented in parliament-namely the pro-Islamic AKP, secular centre-left CHP, ultranationalist MHP, and the then parliamentary representative of the pro-Kurdish forces BDP2 (Barışve Demokrasi Partisi - Peace and Democracy Party) — formed a constitutional commission and agreed on a partial draft of 60 articles. The parties continued working on a new Constitution in the aftermath of the 2015 general elections, but the commission was dissolved in February 2016 after the CHP categorically rejected the instatement of a presidential system, which the AKP persistently advocated (BBC Türkçe 2016). The AKP then moved to write its own draft Constitution. Yet, the party lacked the qualified majority of two-thirds of MPs required to amend the Constitution. Instead it sought the support of 330 MPs (out of the total of 550) required to submit the constitutional package to a referendum. Having only 316 seats in the parliament, the AKP needed some support from the opposition to achieve this majority. This process, stalled until the July 2016 failed coup attempt, gained momentum when the MHP leader Devlet Bahçeli declared his support for heightened powers for the president on the condition that the first four articles of the existing constitution remained intact. ${ }^{3}$

Accepting these conditions, the AKP single-handedly prepared a draft Constitution and dismissed the earlier consensus reached by the four major parties on 60 articles. The central focus of the new draft was to instate an executive presidency, which would institutionalise Erdoğan's de facto yet unconstitutional power and influence over the executive. Composed of 18 amendments affecting 72 articles, the package proposed a number of critical changes 
in the Turkish political system: (1) the executive and the legislative branches are separated and the president is both the head of the state and the executive with no separate office of the prime minister; (2) the president is directly elected in popular elections every five years by a majority of the popular vote and can serve two terms, with a third term allowed in a case where the parliament or the president calls for early elections during the president's second term; (3) the president appoints and dismisses his (unspecified number of) deputies, the ministers, and high ranking officials without parliamentary oversight or approval; (4) the president can issue executive orders on a wide range of issues-including the creation of new ministries, organisation of local governance, and other aspects of social and economic life-except issues pertaining to fundamental rights and liberties and those already organised by existing legislation, with presidential decrees remaining in effect until the parliament overrides them with legislation; (5) the parliament retains its authority to legislate, pass the budget, and declare war, yet with limited oversight over the executive branch: it can submit written questions to the president's deputies and to government ministers but not to the president; (6) the number of MPs is increased from 550 to 600 and parliament can initiate an investigation into the president and ministers with a three-fifths majority; (7) the number of members of the Constitutional Court is decreased to 15 and of the Council of Judges and Prosecutors to 13, with the president appointing five members to the Council and the parliament electing another five while the minister and deputy minister of justice are ex officio members of the Council; (8) the age limit for MPs is lowered to 18; (9) martial law and military courts are abolished. ${ }^{4}$

Once the commission forwarded the proposal to parliament, the AKP used its majority to dominate the debates. As a result, in the fast-track discussions, the opposition MPs found limited opportunity to discuss the individual articles, while the speaker of the parliament did not ensure the broadcasting of the sessions on public television, ultimately denying the people access to parliamentary deliberations. ${ }^{5}$ Finally, the MPs of both the AKP and MHP cast open votes on the package, violating the norms of secret voting for constitutional amendments (Cumhuriyet 2017a). With the support of the MHP leadership, despite many heated discussions in parliament, the constitutional package received 339 votes, opening the path for a new constitutional referendum. Both the AKP and MHP leaders were confident that the majority of the Turkish people would endorse the package given their electoral support of 60 per cent in the the November 2015 elections (see Table 2). Indeed public opinion surveys prior to the referendum indicated a close relationship between partisanship and support for a presidential system (Aytaç et al. 2017).

\section{The 'Yes' campaign}

The 'Yes' bloc was primarily composed of the ruling AKP and the ultra-nationalist MHP with some support from a few fringe parties, namely the ultra-nationalist Islamist BBP (Büyük Birlik Partisi - Great Unity Party) and the Kurdish-Islamist Hüda-Par (Hür-Dava Partisi - Free Cause Party). ${ }^{6}$ As expected, the AKP led the'Yes' campaign since President Erdoğan had been a vocal advocate for a presidential system in Turkey and was the principal proponent of the system change in his party. Both PM Yıldırım and President Erdoğan, despite the constitutional provision that the president should be non-partisan, campaigned in favour of the referendum package. Leaders held joint rallies in five major cities and complementary rallies in more than 75 (out of 81) cities. Erdoğan visited more than 30 cities while Yıldırım visited another 
47 for the 'Yes' campaign (Sabah 2017). Erdoğan's rallies were either sponsored by the 'Yes Platform' - since the president is supposed to be non-partisan according to the 1982 Constitution and cannot campaign on behalf of a political party_or financed by the state as public ceremonies marking grand openings.

\section{AKP: strong presidency for political stability and effective governance}

The AKP's official referendum campaign-as run by the party leaders and supported by Erdoğan —highlighted a number of issues. First, the party emphasised governmental stability under a presidential system over potential flaws of the existing parliamentary system with a strong president. To that effect, the AKP underlined the need to replace the duality in the executive branch (embodied by the prime minister and the president) with a strong presidency, which would govern the country for a fixed term of five years. Likewise, a presidential system would alleviate the uncertainties associated with the parliamentary system. As such, Turkey could, the AKP hoped, avoid repeating the weak and ineffective coalition governments of the 1990s, which were often blamed for the economic troubles and political instability of what many called 'the lost decade'. Secondly, the party argued, the parliamentary system suffered from a particular democratic deficit since it opens the political system to the undue influence of 'tutelary' powers, i.e. the military, the media bosses, judiciary. Such influence, according to the party, was particularly intense under coalition governments, which were often formed 'behind closed doors'. Therefore, throughout its campaign, the AKP blamed the parliamentary system for the military interventions of 1960, 1971 , and 1980, the economic underperformance of the 1990s, the economic-political crisis of 2001, and the post-election violence in June 2015 (Habertürk 2017b; T24 2017a).

The presidential system, on the other hand, the party suggested, is a panacea for such flaws. A strong executive presidency, the AKP promised, would translate the people's will directly into presidential authority (bypassing the representatives in parliament) at the expense of tutelary powers - the military and the judiciary-hence increasing the democratic legitimacy of the system. The party also argued that the democratic quality of the regime would further improve since the president has to appeal to broad segments of society to win a majority of the votes. A strong presidency would also deliver effective governance, circumvent bureaucratic hurdles, provide governmental stability, ensure economic growth, increase investments and employment, provide heightened security, and put an end to terrorism (AKP 2017). It is noteworthy that the AKP leaders avoided discussing the potential gridlock that could arise in a case where the president and the parliamentary majority came from different political parties.

Besides these promises, the AKP referendum campaign also rested on delegitimisation of the 'No' vote. The AKP relied heavily on negative campaigning by discrediting and delegitimising those who contested the proposed changes, evoking a deep polarity between 'the people' (yes) and 'its enemies' (no). Accordingly, PM Yıldırım, President Erdoğan and several government ministers invoked conservative nationalist rhetoric to portray naysayers as traitors and terrorists with the aim of receiving the support of undecided voters within the conservative-nationalist constituency. Minister of Justice Bozdağ, for instance, claimed that all terrorist organisations-including FETÖ, DHKP-C, the PKK ${ }^{7}$ - and legal political parties - such as the CHP and the HDP — were working together to defeat the referendum package (T24 2017b). PM Yıldırım in the same vein frequently asserted that the AKP was 
supporting constitutional change because the PKK, FETÖ, and the HDP were against it (NTV 2017). President Erdoğan on a number of occasions equated naysayers with those who attempted the failed coup in July 2016 (T24 2017c) and claimed that voting 'No' in the referendum would be a vote in favour of the PKK, as those who contest 'the people's will' and the Turkish flag indeed oppose the constitutional package (T24 2017d). Both President Erdoğan and PM Yıldırım also repeatedly accused the main opposition party CHP of acting in concert with the PKK (NTV 2017).

The AKP also capitalised on its performance legitimacy to garner support for constitutional change. In their rallies, both PM Yıldırım and President Erdoğan pointed to economic growth under the AKP governments, public investments, health-care reforms, and specific public projects developed in local provinces as reasons to vote'yes' in the referendum. Both leaders promised that the new system would further improve government performance, ensuring more growth, employment, and investments, as well as numerous infrastructure projects around the country.

Finally, the AKP campaign invoked religious sentiments in favour of constitutional change. In his speeches Erdoğan warned the voters not to jeopardise 'their life and afterlife' by opposing the executive presidency (Yeniçağ 2017c) and identified the constitutional reform process as a 'sacred journey' (kutlu yolculuk), a phrase often used in Turkish in reference to the Islamic pilgrimage to Mecca (Hajj) (Aljazeera 2017). He also argued that consenting to evil was itself evil-referring to the rejection of the executive presidency (Hürriyet 2017a). Meanwhile, his well-known piety was underlined throughout the campaign. A case in point concerns pictures with his grandson, showing Erdoğan teaching the Qur'an (AHaber 2017). Some mosques controlled by the Diyanet (Directorate of Religious Affairs) also played an important role in the referendum as several preachers campaigned in favour of constitutional changes, calling the naysayers 'traitors' or 'coup-plotters' in their sermons (Almonitor 2017). This was clearly reminiscent of the role the mosques played on the night of the July 2016 coup attempt and during its aftermath (Esen \& Gümüşçü, 2017). Further enhancing the fusion of Islam and politics in Turkey, columnists in the pro-AKP media identified the proposed changes as a defence of Islam and a struggle for the salvation of umma (community of Muslims). ${ }^{8}$ Hayrettin Karaman, a renowned religious scholar with significant influence over Erdoğan and his constituency, further argued that a 'Yes' vote should be seen as a religious duty (Karaman 2017).

This discourse was further pronounced over the course of a diplomatic crisis with several EU member states, particularly the Netherlands, in the midst of the campaign. To receive the support of the diaspora voters, the AKP government organised rallies in a number of European countries, most of which cancelled the events due to security concerns (T24 2017e). Meanwhile, the Dutch government denied access to Turkey's Foreign Minister, Çavuşoğlu, and declared the Minister of Family and Social Affairs Fatma Betül Sayan Kaya persona non grata after expelling her to Germany along with her aides, when she tried to enter the country via the German-Dutch border (T24 2017f). This diplomatic crisis allowed the AKP to successfully internationalise the campaign (Dunham \& Hintz 2017). It not only generated a popular backlash in Turkey and triggered a set of angry responses by AKP cabinet members as well as President Erdoğan (Henley 2017), but also lent support to AKP's portrayal of naysayers as a coalition of 'enemies of the people' within and outside of Turkey. Evoking the fear of encirclement and nationalist fervour meshed with religious sentiments among conservative Turks, Erdoğan depicted the referendum as a response to the European Union, which allegedly acts as 'a crusader alliance' (Hürriyet 2017b). 


\section{MHP: for a stronger Turkey under an executive presidency}

Unlike the 2010 referendum campaign, during which the governing AKP received support from numerous parties and political groups (Ciddi 2011), the constitutional amendments voted in 2017 encountered widespread opposition from the political class. As mentioned above, only the ultra-nationalist MHP and two minor parties supported the constitutional amendments. ${ }^{9}$ Even the Islamist SP (Felicity Party - Saadet Partisi) ${ }^{10}$ rejected the constitutional amendments, portraying the proposed system as dictatorial (Hürriyet 2017c). The ultranationalist MHP, established in the 1970s, has remained as a minor party with fluctuating electoral support over the years. Since the AKP's rise to power in 2002, however, the MHP had become a vocal opponent of the government expressing strong criticism of the AKP's Kurdish policies and Erdoğan's call for a presidential system. ${ }^{11}$ Given this strong criticism of Erdoğan in recent years, the MHP leader's support for the constitutional change met with utmost surprise among the political establishment.

Many theories abound to account for the long-time MHP leader Bahçeli's recent turnaround but few can explain his rationale in clear terms. One such argument suggests that Erdoğan's decision to terminate the Kurdish peace process in 2015 brought the two parties closer on a common Turkish conservative-nationalist platform. Another argument attributes Bahçeli's decision to his weakness in the party in relation to his opponents. According to this view, Bahçeli lent support to the constitutional amendments in exchange for the government's help in thwarting his rivals. Lastly, some mention the existence of a post-referendum agreement between the two parties, with the MHP getting a presidential slot as well as guaranteed seats in parliament and positions in the bureaucracy. In the meantime, Bahçeli denied that he was interested in the vice-presidency (Milliyet 2017). Regardless of his reasoning, Bahçeli's open support for the'Yes' side exacerbated the rifts in the MHP, limiting the impact of the party's campaign. Faced with leadership challenges, embattled Bahçeli spent most of his campaign attacking his critics in the party and proved not to be a reliable ally in the 'Yes' camp.

The MHP organised few public rallies during the campaign and instead preferred to hold closed-door meetings. The MHP's role in the campaign was to persuade undecided MHP voters on the necessity of the proposed system, despite Bahçeli's strong criticisms against the presidential system in the past. Many rank and file members were worried that the constitutional amendments could lead to the imposition of a federal system, giving vast local autonomy to the Kurdish-populated Southeastern provinces. The MHP leadership put forward several arguments to assure their voters that the constitutional amendments would not result in Turkey's dismemberment. First, the party stressed that the constitutional amendments did not constitute regime change but would merely legalise the strong presidency that had emerged after the switch to a directly elected presidency in 2014 (Birgün 2017). The MHP leaders also denied the assertion that the presidential system would pave the way to a federal regime. On numerous occasions, the party gave assurances that the first four articles of the constitution would not be amended under any circumstances.

During the campaign, Bahçeli put forward two main arguments to support the'Yes' side. First, he emphasised the need to legalise Erdoğan's de facto power, ending the current constitutional chaos caused by the president's frequent extra-constitutional political interventions, and bringing stability to the country in the aftermath of the failed coup. According to this view, Erdoğan's recent attempts to govern directly by going beyond his 
constitutional prerogatives created an urgent need to define the parameters of presidential power through wide consensus even if that meant heightened powers for the president. Second, Bahçeli characterised Turkey as an encircled country that is under attack by both foreign and domestic enemies. The 'Yes' vote would counter such threats by strengthening the political system. Interestingly, the MHP failed to keep party discipline throughout the campaign as many dissidents in the party joined the 'No' campaign. The party did not tolerate dissent within its ranks on the referendum: it expelled these MPs (BBC 2017) and disbanded many local chapters due to their open support for the 'No' camp.

\section{The 'No' campaign}

In contrast to the'Yes' campaign, the 'No' bloc hosted a variety of actors across the ideological spectrum. The Islamist SP and factions within the ultra-nationalist MHP joined the secular CHP and pro-Kurdish HDP as well as numerous civil society organisations to defeat the constitutional reform at the ballot box. That said, the CHP campaign proved to be the flagship of the 'No' campaign.

\section{CHP: against one-man rule}

As the oldest political party in Turkey, the CHP represents the republican, secular, and modernist ideals of founding fathers like Mustafa Kemal Atatürk and İsmet İnönü. Receiving the support of a quarter of the electorate, the CHP is traditionally a party of the secular urban middle classes and serves as the main opposition party to the conservative agenda of the AKP government. Since the AKP's victory in the November 2002 elections, Turkish politics has been defined by a 'long-running kulturkampf between the secularists and the Islamic revivalists' (Kalaycıoğlu 2012) whereby religiosity became a major factor in Turkish voting behaviour (Çarkoğlu 2007; Kalaycıoğlu 2012). By pitting religious conservative voters located in low-income neighborhoods against middle-class secular voters, Erdoğan managed to secure electoral majorities in successive elections. Receiving a high level of support from middle-class secularists, the CHP had turned into a regional party that has appeal primarily for'minority electoral constituencies' in coastal areas and major cities (Magaloni 2006; Greene 2007). Given that the combined vote share of AKP and MHP in November 2015 surpassed 60 per cent, the CHP elites knew the'Yes' vote would prevail easily in the event of polarisation over cultural issues during the campaign. Therefore, the main opposition party built its strategy on neutralising the AKP's polarising discourse and waged a non-partisan campaign that appealed to voters from different political backgrounds.

The party led an effective campaign that focused on the content of the constitutional amendments. Kılıçdaroğlu was careful to not get into polemics with Erdoğan and defended the parliamentary regime without directly attacking the AKP government. The CHP leadership also tried to lower the stakes for AKP voters who wanted to reject the constitutional amendments, by arguing that the 'No' vote would not change the political status quo. If the constitutional amendments were rejected in the referendum, the party leaders pointed out, Erdoğan would still remain as president and the AKP as governing party. Kılıçdaroğlu publicly stated that his party would not challenge the legitimacy of Erdoğan's presidency should the 'No' vote prevail on 16 April. 
The CHP vehemently rejected the AKP's claim that the presidential system could ever solve Turkey's long-lasting problems. As it had done in the elections of June (Kemahlıoğlu 2015) and November 2015 (Sayarı 2016a), the CHP portrayed the constitutional amendments as a deliberate plan by Erdoğan to establish his personal rule. Kılıçdaroğlu tried to draw parallels between the proposed regime and Turkey's military rule between 1980 and 1983, based on the enormous powers given to the president in both cases. According to the $\mathrm{CHP}$ spokespeople, the proposed amendments were so comprehensive that no single person could ever be trusted with the exercise of such powers. Furthermore, the CHP campaign warned that the new system would greatly diminish parliament's powers and render the legislative body ineffective against the executive president. Lastly, the nationalist (ulusalcı) wing of the party appealed to moderate MHP voters who were puzzled by Bahçeli's dramatic shift, by suggesting that the presidential system was a prelude to the adoption of a federal regime.

\section{MHP dissidents: No to MHP leadership, No to executive presidency}

The main opposition CHP was not alone in the 'No' camp. Bahçeli's rivals criticised the MHP's decision to support the constitutional amendments and challenged the party line openly with a'Turkish Nationalists Say No Campaign' (Yeniçağ 2017a). Former and current parliament members from the MHP like Meral Akşener, Ümit Özdağ, Sinan Oğan, and Koray Aydın, as well as numerous mid-level party officials, turned their opposition against Bahçeli into a campaign against the Yes side. ${ }^{12}$ Their vocal and lively campaign constituted a major blow to Erdoğan's efforts to secure a clear majority in the referendum. In addition to dividing the MHP vote, their campaign also limited the AKP's efforts to portray the'No' camp as an alliance of terrorist groups like the PKK and the Gülenists (FETÖ). Given their Turkish nationalist backgrounds, the campaign waged by credible figures like Akşener and Özdağ made it easier for nationalist voters to oppose the constitutional amendments without fearing that they were siding with the CHP or the PKK.

The naysayers' challenge was particularly directed at the MHP leader, Devlet Bahçeli, and thus became a continuation of their earlier efforts to unseat the MHP leader. During the campaign, these figures tried to persuade the MHP rank and file members that theirs was the best course of action for the party. On numerous occasions, they claimed that the executive presidential system to be voted for in the referendum would wipe out the MHP electorally since the party could only thrive against the governing AKP machine in a parliamentary system. Moreover, they argued that Bahçeli's support for the constitutional amendments stemmed not from his desire to protect the state, as he claimed, but rather to protect his leadership. In particular, Akşener accused Bahçeli of putting his own political interests before those of the country and the party (Yurt 2017).

Among Bahçeli's critics, Akşener and Oğan were most active in touring the country to hold public meetings. These events were more effective and drew larger crowds than those organised by the party leadership. For many mid-level MHP officials, these party members represented the future of the party and many did not hesitate to work together with Akşener and Oğan, among others. In a leader-centric party like MHP, there was no historical precedent to such an open challenge against the party's sitting chairman. ${ }^{13}$ Meetings organised by Bahçeli's critics frustrated the MHP leadership and led to intra-party fighting. Several events organised by Akşener, Oğan, and Özdağ (T24 2017g) were disrupted by pro-Bahçeli supporters, with the police taking only limited action (Posta 2017). 


\section{HDP: a parliamentary system for democracy, human rights, and pluralism}

The pro-Kurdish HDP was another key political actor that opposed the constitutional package. Established in 2012 and dominated by the Kurdish movement after the 2014 merger of the BDP and the HDP, the HDP attempted to go beyond its pro-Kurdish concerns by reaching non-Kurdish constituencies with a more inclusive and leftist platform. Indeed, as part of this agenda the party had adapted a strong and vocal opposition to Erdoğan's plans to establish an executive presidency, and placed this issue at the centre of its electoral campaign in the June 2015 elections with the slogan 'we will not make you the president' (Kemahlıoğlu 2015). Partly due to its vocal opposition to a presidential system, the HDP became the first pro-Kurdish party to pass the national electoral threshold of ten per cent, thanks to critical support from the urban middle classes of Turkish origin and conservative Kurds. This success briefly cost the AKP its parliamentary majority, which the government had maintained since 2002.

In the wake of the June 2015 election, both the government and the PKK withdrew from the already stalled peace process and a cycle of violence erupted in urban centres in the Southeast. The AKP government responded to the PKK's insurgent attacks with long-lasting curfews and other urban counter-insurgency measures. Over the course of this conflict, 321 civilians died, 100,000 civilians were displaced, and about a million others were affected by the destruction of city centres (Aydın \& Emrence 2016). Aydın and Emrence find that the AKP government selected curfew towns among the HDP strongholds and not necessarily among the foci of insurgent activity. The strategically imposed curfews, the authors claim, led to increased votes for the AKP and reduced support for the HDP in the November 2015 snap elections.

The government, reluctant to distinguish the legal political party HDP from the PKK which is proscribed as a terrorist organisation, targeted the HDP's organisational infrastructure and crippled the party in the wake of the July 2016 coup attempt. The parliament voted to lift the parliamentary immunity of several MPs, and as a result 13 HDP MPs, including the two co-chairpersons, Selahattin Demirtaş and Figen Yüksekdağ, were imprisoned. Throughout the referendum campaign the HDP leaders and 11 other MPs were in prison awaiting trial. Moreover, the security forces raided several HDP local offices and arrested hundreds of midlevel party officials throughout the campaign cycle. Furthermore, the AKP government, using the emergency law as a pretext, took over 84 municipal governments governed by mayors belonging to the pro-Kurdish DBP (Demokratik Bölgeler Partisi - Democratic Regions Party) due to their alleged ties to the PKK; all the mayors were arrested (OSCE 2017).

Thus in clear contrast to its vibrant June 2015 campaign, HDP's referendum campaign was much weaker and less lively. At the outset, the party expressed its opposition to the referendum package and voted against the new draft in the parliament. However, the party's opposition did not translate into a strong presence on the campaign trail. As anticipated, the themes of the HDP campaign revolved around issues of democracy, human rights, and pluralism. The party highlighted the government crackdown on the opposition in general and the Kurdish movement in particular due to the emergency law in effect since July 2016. The HDP criticised the draft constitution for bringing one-man rule, centralisation of power in the office of the presidency, and a conservative-nationalist and sexist political vision in line with the ideological alignment between the AKP and the MHP. The party was particularly concerned with the decreasing power of parliament and the president's increasing power 
over the legislative and judicial branches. Hence the HDP referred to this draft as an updated version of the 1982 Constitution and an instrument to institutionalise Erdoğan's de facto executive presidency. The party argued that this draft was a far cry from a civilian and democratic constitution with an emphasis on decentralisation, democratisation, pluralism, women's rights, and ecological concerns (HDP 2017). Finally, the party reinforced the overall sentiment among the Kurdish people that the constitutional package had no benefits or promises for Kurds at a time of violence in the Southeast.

\section{Uneven playing field}

Despite its flaws and occasional military coups, Turkish democracy was commendable up until recently in the free, fair, and regular elections held since 1950. The playing field was broadly even and systematic electoral fraud was nonexistent. With the AKP's rise to dominance and its authoritarian direction after 2011, however, the playing field in Turkey tilted in favour of the ruling party to create a competitive authoritarian regime (Esen \& Gümüşçü 2016; Özbudun 2015; Sayarı 2016b). As a result, recent elections have been marred by the ruling party's disproportionate access to the media and to private and by public resources and increasing politicisation of the state institutions. This referendum was no exception. Indeed the emergency law in effect since July 2016 exacerbated many of these trends over the course of the referendum cycle (OSCE 2017).

While the 'Yes' campaign benefitted from extensive resources and media support, the 'No' campaign faced serious resource disadvantages, constant harassment from public officials, and limited access to the media as well as public space. The president and prime minister held large gatherings for official ceremonies financed by the state budget; most of these gatherings turned into campaign rallies attended by public sector employees and students who were required to attend (OSCE 2017, pp. 7-8). Meanwhile, the emergency law particularly proved to be instrumental in restricting the freedom of assembly and the opposition's access to public spaces.

State officials erected a number of hurdles on the campaign trail for the No bloc. While these restrictions targeted the entire'No' campaign, regardless of different parties' ideological positions, the pro-Kurdish HDP was particularly hard hit. Indeed, the YSK decided that civil society organisations and associations could not run campaigns and recognised only ten political parties as eligible to campaign (OSCE, 2017). Despite being one of the eligible parties, public space was severely restricted for the pro-Kurdish party, in line with the AKP's rhetoric that the 'No' vote would be supporting 'the PKK-HDP camp'. As already discussed, the co-chairpersons of the HDP were imprisoned along with 11 more MPs; thousands of officials of the HDP local chapters were arrested, ultimately stripping the party of its voice and ability to run an effective campaign. To debilitate the HDP campaign even further, public officials continued the crackdown on the party by banning its campaign song and towing away its campaign vehicles.

Those actors in the 'No' campaign without a legal organisational standing or campaign eligibility were particularly vulnerable to such pressures. For instance, the opposition figures within the MHP became a primary target. Provincial governors denied naysayers in the MHP permits for rallies and meetings in several cities_Ankara, Denizli, Niğde among them-using the emergency law as a pretext (Cumhuriyet 2017c; Yeniçağ 2017b). In other cities, such as 
Çanakkale and Edirne for instance, where Akşener could obtain a permit, local figures denied access to their facilities or logistical support in conference rooms (T24 2017g).

Along similar lines, more than hundred activists from political parties and associations were detained over the course of the referendum cycle for security reasons (OSCE 2017). Several individuals hanging posters and banners opposing the presidential system were given fines for vandalism. Furthermore, naysayers were physically attacked during campaigning by pro-government vigilantes, especially in AKP-dominated areas (OSCE 2017: 8). Finally, the governor of Ankara banned all protests in January 2017, shutting the public space in the capital city to citizens until the referendum.

Equally important, media access was restricted for almost all naysayers to different degrees. On the five television stations which the OSCE monitored throughout the campaign period, the 'Yes' campaign featured in 76 per cent of airtime devoted to the campaign as opposed to 23.5 per cent for the 'No' campaign (OSCE 2007: 11). In the 'No' camp, the HDP (0.6 per cent) and the MHP naysayers were almost completely absent from mainstream media, while the CHP (19 per cent) could find limited opportunities to appear on national networks. The airtime on national stations, however, was clearly allocated in favour of the ruling party (33.5 per cent). Not surprisingly, the stakeholders filed numerous complaints to the YSK and RTÜK (Radio Television Supreme Board - Radyo ve Televizyon Üst Kurulu) - but to no avail, for an executive decree (No. 687) dated 9 February 2017 had repealed the YSK's authority to sanction the media in order to ensure equal airtime for different parties over the course of the campaign. ${ }^{14,15}$

Last but definitely not least, the YSK further pushed the playing field in favour of the AKP. First, the Board moved polling stations in predominantly Kurdish areas and relocated them in distant villages dominated by pro-government rangers. This relocation undermined citizens' access to the ballot boxes and impeded the HDP's capacity to mobilise its constituency. Second, among the approximately half a million people, who had to flee from their homes after July 2015 due to escalating violence between the PKK and the state and the government's counter-insurgency measures, voter registration was limited (OSCE 2017: 6). Third, in some Kurdish towns and villages, such as Hakkari, Batman, Siirt and Nusaybin, the YSK disqualified hundreds of election observers from the HDP (and the CHP) ranks, leaving many ballot box committees without opposition monitoring (Cumhuriyet 2017d).

More importantly, during the voting process on election day the YSK made changes in the vote counting procedures and accepted all unstamped ballots as valid - upon the AKP's request - thus rendering the entire process vulnerable to fraud by lifting a critical safeguard (CNNTürk 2017). This decision was unprecedented and in clear violation of the stipulations of electoral law (Seçim Kanunu 1961). Indeed the YSK had ruled in favour of unstamped ballots in the past but such decisions had been taken on a case-by-case basis at the level of individual polling stations, and not as a blanket pass for all unstamped ballots. Although there is no reliable data on the geographical or vote distribution of unstamped ballots, it is safe to claim that the slim difference between the 'Yes' and 'No' vote substantially raised the stakes of YSK's decision. This last minute change created a significant stir within the opposition and led to questioning of the legitimacy of the referendum results (New York Times 2017). Regardless of its impact on the outcome, the YSK's decision to validate unstamped ballots undermined the credibility of the process and trust in the electoral institutions and the rule of law. 


\section{Referendum results}

The 2017 referendum campaign was hard-fought between the two camps, as evidenced by the close margin of victory for the 'Yes' campaign. In Turkey itself, 24.3 million voters (51.2 per cent) cast their ballot for 'Yes' against 23.1 million 'No' voters (48.8 per cent). Among diaspora voters, who constitute approximately five per cent of the overall electorate, support for the'Yes' camp was higher, at 58.4 per cent. The inclusion of the diaspora vote marginally increased the margin of victory for the 'Yes' camp to 51.4 per cent. At 87.3 per cent, the turnout rate far exceeded levels seen in the 2010 constitutional referendum ${ }^{16}$ and the 2014 presidential elections. The provinces with the highest turnout were located in the Aegean region, while those in the Eastern and Southeastern parts of the country had much lower rates (Table 3). Given that tens of thousands of people were forced to vacate their houses after the start of military operations in the region against the PKK in summer 2015, the lower rates in Kurdish-populated provinces should not come as a surprise.

As shown in Table 4, the ten provinces with the highest percentage of 'No' votes are located in geographically and politically diverse parts of the country, namely the CHP strongholds in the Thrace and Aegean provinces (Kırklareli, Edirne, Muğla, and İzmir) coupled with the heavily Kurdish-populated Southeastern provinces (Şırnak, Diyarbakır, and Hakkari). Meanwhile, the 'Yes' vote peaked in the socially conservative and economically underdeveloped Eastern Black Sea, Central and Eastern Anatolian provinces, where the AKP has been dominant since 2002 (Figure 2).

Table 3. Provinces with the highest and lowest turnout rates in the Turkish referendum of April 2017 (\%).

\begin{tabular}{lccc}
\hline Lowest turnout & \multicolumn{2}{c}{ Highest turnout } \\
\hline Province & $\%$ & Province & 90.5 \\
\hline Ağrı & 71.1 & Bilecik & 90.4 \\
Gümüşhane & 73.1 & Manisa & 90.3 \\
Van & 75.4 & Amasya & 90.3 \\
lğdır & 76.8 & Denizli & 90.3 \\
Kars & 78.0 & Çanakkale & 90.2 \\
Bingöl & 78.1 & Kütahya & 90.2 \\
Bitlis & 78.5 & Uşak & 90.1 \\
Muş & 79.0 & Düzce & 90.0 \\
Ardahan & 79.9 & Kırklareli & 89.8 \\
Diyarbakır & 80.7 & Ankara & \\
\hline
\end{tabular}

Table 4. Highest 'Yes' and 'No' votes in the Turkish referendum of April 2017 by province.

\begin{tabular}{lccc}
\hline \multicolumn{1}{c}{ NO } & \multicolumn{2}{c}{ YES } \\
\hline Province & \% of the vote & Province & \% of the vote \\
\hline Tunceli & 80.4 & Bayburt & 81.7 \\
Sıırnak & 71.7 & Rize & 75.5 \\
Kırklareli & 71.3 & Aksaray & 75.5 \\
Edirne & 70.5 & Gümüşhane & 75.2 \\
Muğla & 69.3 & Erzurum & 74.5 \\
İzmir & 68.8 & Yozgat & 74.3 \\
Diyarbakır & 67.6 & Kahramanmaraş & 73.9 \\
Hakkari & 67.6 & Çankırı & 73.5 \\
Iğdır & 65.2 & Konya & 72.9 \\
Aydın & 64.3 & Bingöl & 72.6 \\
\hline
\end{tabular}


There was a high degree of variation in vote distribution among the country's seven regions (see Table 5). The 'Yes' vote reached its highest levels in the AKP's traditional strongholds, namely the Black Sea (62.6 per cent), Central Anatolia (58.5 per cent), and Eastern Anatolia (57.6 per cent) regions. In the heavily Kurdish-populated Southeast Anatolia region, the'Yes' vote came out on top (52.9 per cent) but with a smaller margin. By contrast, the 'Yes' vote decreased in the more developed and secular Aegean (39.8 per cent) and Mediterranean (46.1 per cent) as well as Marmara (49.2 per cent) regions. Compared to the 2010 constitutional referendum, which passed with 58 per cent of the voter, the 'Yes' vote was lower in all seven regions.

The 'Yes' bloc, composed of AKP and MHP, seems to have lost over 10 per cent of its electoral strength since the November 2015 general elections. In a constitutional referendum, not all voters can be expected to follow their party line but the gap was quite significant in this case. The 'Yes' vote was lower than these parties' combined vote share in all but 13 cities, as seen in Table 6. These 13 cities are all located in East and Southeast Anatolian regions and many are currently administered by government-appointed mayors, who replaced the Kurdish mayors during the state of emergency. This regional anomaly, coupled with the unstamped ballot decision and the state efforts to block HDP observers, caused some alarm about the reliability of these results in the area.

Of the 68 cities where the referendum vote for 'Yes' vote was lower than the AKP-MHP vote in November 2015, the drop exceeded 10 per cent of the vote share in 47 of them. In Osmaniye (23.5 per cent), Kırşehir (21.7 per cent), and Kırıkkale (20.8 per cent), which are Table 5. Results of the Turkish constitutional referendums of 2010 and 2017 by region (\%).

\begin{tabular}{lcccc}
\hline & \multicolumn{2}{c}{ YES } & \multicolumn{2}{c}{ NO } \\
\cline { 2 - 5 } Regions & 2010 & 2017 & 2010 & 2017 \\
\hline Marmara & 53.2 & 49.2 & 46.8 & 50.8 \\
Aegean & 43.8 & 39.8 & 56.2 & 60.2 \\
Black Sea & 64.4 & 62.6 & 35.6 & 37.4 \\
Central Anatolia & 63.9 & 58.5 & 36.1 & 41.5 \\
Eastern Anatolia & 81.3 & 57.6 & 18.7 & 42.4 \\
Southeastern Anatolia & 84.0 & 52.9 & 16.0 & 47.0 \\
Mediterranean & 48.7 & 46.1 & 51.3 & 53.8 \\
\hline
\end{tabular}

Table 6. Largest decline in AKP-MHP support from the November 2015 elections to the April 2017 referendum by province (\%).

\begin{tabular}{|c|c|c|c|c|c|}
\hline \multirow[b]{2}{*}{ Province } & \multicolumn{3}{|c|}{2015 November elections } & \multicolumn{2}{|c|}{2017 referendum } \\
\hline & AKP & MHP & TotalAKP+MHP & Yes votes & $\begin{array}{c}\text { Difference between } \\
2017 \text { Yes vote and } \\
\text { Nov } 2015 \text { AKP-MHP } \\
\text { support }\end{array}$ \\
\hline Osmaniye & 46.8 & 34.6 & 81.3 & 57.8 & -23.5 \\
\hline Kırşehir & 50.7 & 24.3 & 74.9 & 53.3 & -21.7 \\
\hline Kırıkkale & 62.3 & 20.9 & 83.2 & 62.4 & -20.8 \\
\hline Kilis & 65.6 & 18.4 & 84.0 & 64.1 & -19.9 \\
\hline Karabük & 60.5 & 19.8 & 80.3 & 60.7 & -19.6 \\
\hline Burdur & 50.6 & 19.7 & 70.3 & 51.8 & -18.6 \\
\hline Antalya & 41.3 & 17.6 & 58.9 & 40.9 & -18.0 \\
\hline Uşak & 46.6 & 18.2 & 64.8 & 47.0 & -17.7 \\
\hline Isparta & 53.2 & 20.4 & 73.6 & 56.0 & -17.6 \\
\hline Çankırı & 69.1 & 21.7 & 90.8 & 73.4 & -17.4 \\
\hline
\end{tabular}


historically MHP electoral strongholds (Osmaniye is Bahçeli's hometown), the decrease was over 20 per cent. The 'Yes' camp partly recovered these results by scoring major victories in centres of Anatolian business like Gaziantep (62.5 per cent), Şanlıurfa (70.8 per cent), Erzurum (74.5 per cent), Konya (72.8 per cent), Kocaeli (56.7 per cent), and Kayseri (67.8 per cent), among others. Even in these provinces, however, the 'Yes' vote did not match the AKP and the MHP's vote share in the November 2015 general elections.

This data shows the aggregate changes in votes after the November 2015 general elections but the party preferences of individual voters are not available. We cannot therefore estimate from this data exactly what percentage of the 'Yes' vote came from the AKP and the MHP as well as other parties. A cursory look at the results suggests that the 'Yes' vote generally matched the AKP's vote share in the November 2015 general elections. According to opinion polls, anywhere between half and two-thirds of MHP voters reportedly defied their leaders by choosing 'No' in the referendum (KONDA 2017). Even if we assume that not a single MHP member voted 'Yes', which is not improbable, the 'Yes' vote was still below the AKP vote share in the November 2015 general elections in several major provinces, such as İstanbul, Antalya, Bursa, Denizli, and Eskişehir (see Figures 1 and 2).

Many analysts interpreted these results as a Pyrrhic victory for the governing party, given the unequal playing field during the campaign. Despite limited resources and airtime, the 'No' side came within reach of victory in the referendum. Moreover, the 'No' vote was the clear winner in metropolitan cities and economically developed parts across the country. For instance, it prevailed in five out of the six most populous provinces (Bursa was the only exception). In coastal provinces like Mersin (35.9 per cent), Antalya (40.9 per cent), İzmir (31.2 per cent), and Adana (41.8 per cent), the' 'Yes' vote did not even surpass the 45 per cent level. The most surprising outcome of the referendum, however, was the No victory in the country's top two cities, namely İstanbul (51.4 per cent) and Ankara (51.2 per cent) both of which are run by AKP municipal governments.

As expected, the'No' votes attained high scores in many parts of Southeastern and Eastern Anatolia due to the HDP opposition. However, the 'No' vote remained below the HDP's vote share in the November 2015 general elections across the region (Table 7). In fact, this is the only region where the 'Yes' vote surpassed the combined vote share of the parties in the 'Yes' camp. One possible explanation for this phenomenon is the swing of conservative Kurdish voters, who may have supported the constitutional amendments due to Erdoğan's high popularity. Second, some voters in the region may have reacted negatively to the HDP's failure to curb the PKK's attacks since the June 2015 general elections. Third, we need to note that the referendum was held under extraordinary conditions in the region as a result of the state of emergency. Particularly in districts where the HDP or DBP mayors were replaced by government-appointed trustees, the number of invalid votes was high and the electoral turnout was lower than the national average (KONDA 2017). After the government's operations forced thousands of families to migrate out of these areas, population dynamics have changed. Lastly, we cannot exclude the possibility of electoral irregularities and voter fraud, especially in districts currently run by government-appointed trustees.

Several factors played a role in the surprisingly high 'No' vote in the referendum. First, voters seem to have reacted negatively to the recent economic slowdown that has seen growth rates fall since 2012 (Kalaycıoğlu 2017; Sayarı 2016a). Since the 2016 failed coup, political instability and growing authoritarianism further eroded consumer and investor confidence-with perverse effects for the party's low-income base. Indeed, scholars of 


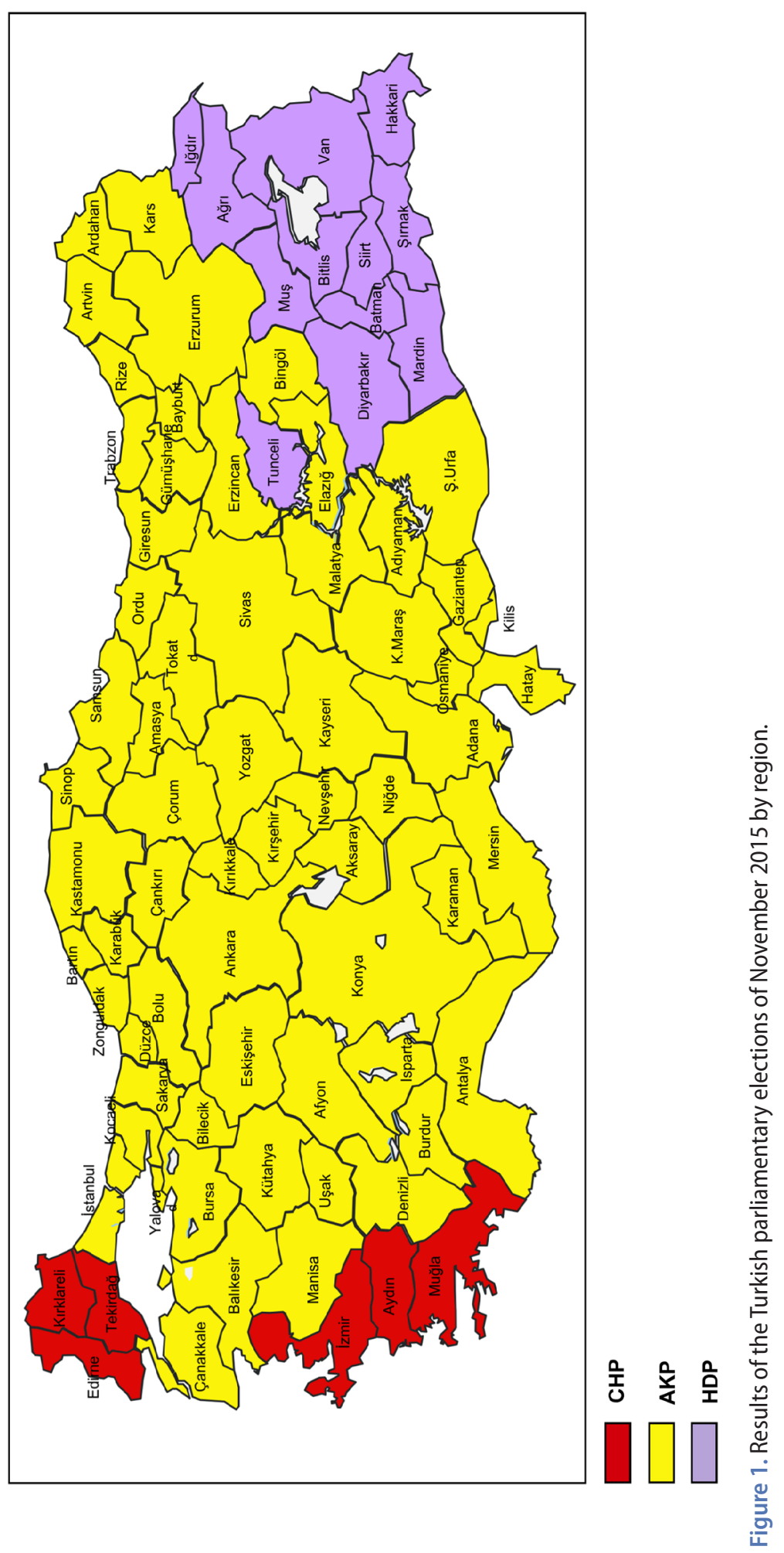




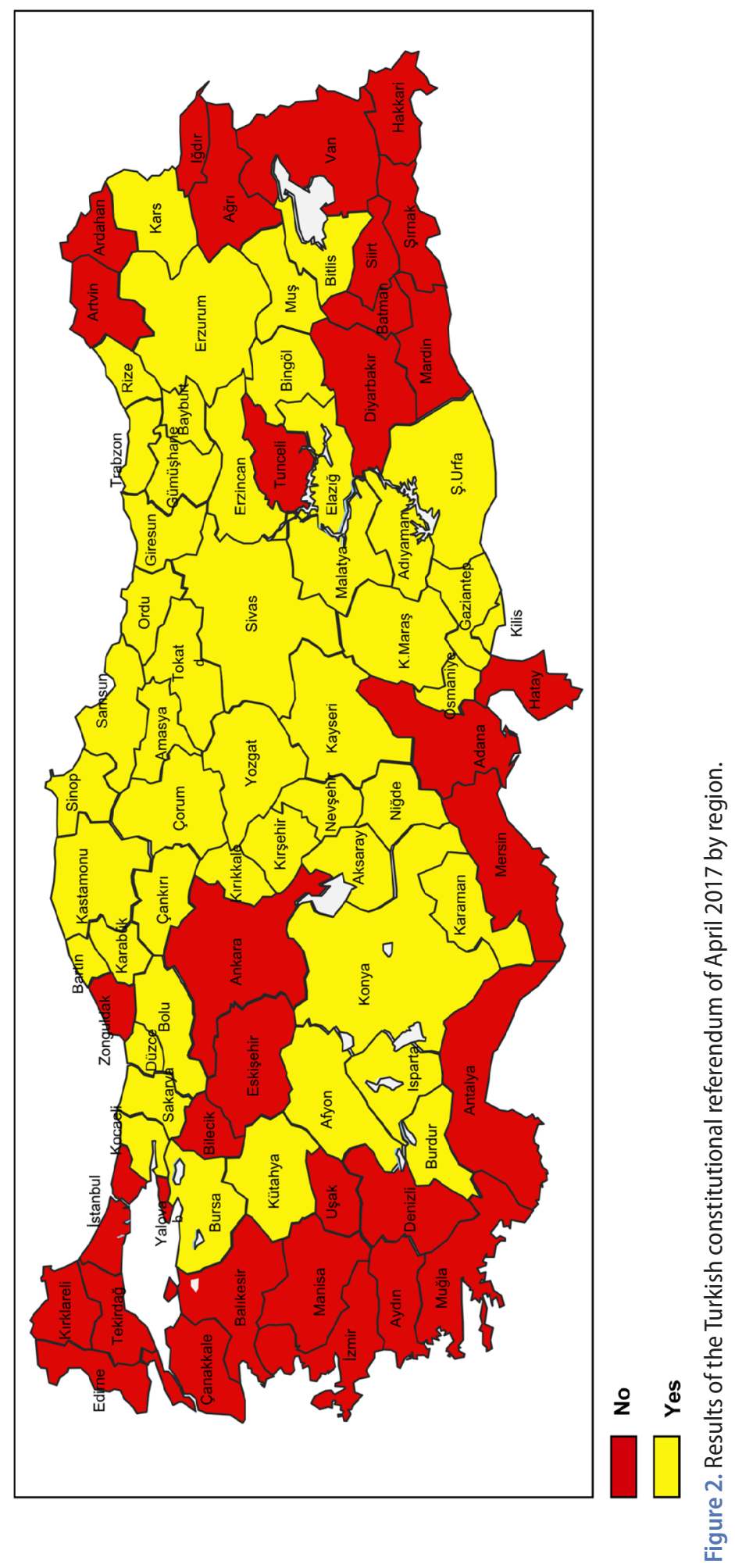


Table 7. Major Kurdish cities: comparing the 2015 November election results with 'No' votes in the April 2017 referendum (\%).

\begin{tabular}{lcccc}
\hline & \multicolumn{3}{c}{ 2015 November elections (\%) } & 2017 referendum (\%) \\
\cline { 2 - 5 } City & CHP & HDP & Total & 'No'votes \\
\hline Sırnak & 1.1 & 85.5 & 86.6 & 71.7 \\
Mardin & 1.3 & 68.4 & 69.7 & 69.3 \\
Diyarbakır & 72.8 & 74.4 & 67.6 \\
Batman & 1.6 & 68.1 & 69.3 & 63.6 \\
Siirt & 1.2 & 58.3 & 59.9 & 42.2 \\
\hline
\end{tabular}

Turkish politics suggest that economic satisfaction plays an important role in the voting behaviour of the Turkish electorate (Başlevent et al. 2005 and 2009; Çarkoğlu 2008; Kalaycıoğlu 2010). For ideologically moderate voters who value economic stability, the party's recent policies were a cause for concern. Some commentators suggest that the AKP base has witnessed a bifurcation between, on the one hand, lower-middle and middle class voters in metropolitan areas, who are very concerned about political stability and economic growth, and on the other hand low-income voters in small towns, rural areas, and the peripheral neighborhoods of metropolitan cities, who are dependent on social assistance provided by the governing party (Çakır 2017). The referendum results, they argue, demonstrated rising discontent with the AKP's policies among the first group of voters. According to opinion polls, while an overwhelming majority of the AKP voters nonetheless cast their ballots for 'Yes', a small number of AKP voters chose 'No' (KONDA 2017: 51). The CHP's depolarising campaign also contributed to this process by lowering the stakes for the 'No' vote.

\section{Conclusion}

The close margin of victory was an upset for President Erdoğan and the ruling AKP, who could not turn their enormous resource advantages along with the MHP's support into a clear mandate for the executive presidency. Opinion polls suggest that the majority of MHP voters rejected the proposed amendments, while the AKP's campaign drew lacklustre support in some of its strongholds in metropolitan cities, resulting in a 'No' victory in five out of the six most populous cities. Moreover, the referendum results were overshadowed by serious allegations of electoral fraud that may have altered the outcome. Given the uneven playing field, the high 'No' vote boosted opposition morale and is viewed as a setback for Erdoğan. The CHP's energetic campaign particularly kept the ideologically diverse'No' camp together under heavy government pressure. At a time when the HDP's organisation crumbled against a barrage of government attacks and Bahçeli's MHP sided with Erdoğan, Kılıçdaroğlu's moderate stance allowed the CHP to lead the 'No' campaign.

Regardless, the referendum will change the Turkish political system in fundamental ways. The new system will transfer power away from parliament to the president, contributing to the ongoing personalisation of executive power. For instance, the legislative body will no longer be able to take a vote of confidence on the government or oversee government actions and will share its prerogatives with the president on numerous policy areas. With weak institutional checks, Erdoğan, if re-elected in 2019, will continue his monopolisation of power, wielding direct influence over the legislative body and his party. Accordingly, 
Erdoğan will continue to govern the country through executive decrees, bypassing the parliament, as he had done since the failed coup attempt. The parliament had become an ineffective body even before the referendum but the adoption of sweeping powers for the president may turn it into a rubber-stamp institution.

The new system is likely to reshape the political landscape. Under the executive presidency, the largest two parties will be in a strong position to gather votes from minor parties, particularly in presidential elections. In particular, the MHP may turn out to be this system's biggest loser. In the near future, the MHP leadership will face an uphill struggle to retain those voters disillusioned by Bahçeli's strong support for Erdoğan's AKP. Given the MHP's current state, many of its voters may flock to the AKP and the CHP, or to the new nationalist centre-right party formed by MHP dissident (at the time of writing the party still had no name). By contrast, despite government attacks and electoral setbacks, the pro-Kurdish HDP will probably maintain enough of its popular base to cross the ten per cent electoral threshold in parliamentary elections but would have a lesser impact on the presidential elections, much like the MHP.

The erosion of parliament's powers might encourage some AKP voters to vote for an opposition party in the legislative elections to restrain the powerful president and hold the ruling AKP accountable for its poor economic performance. Given the AKP's razor-thin electoral majority, Erdoğan may win the presidency but lose his party's majority in the 2019 elections. Paradoxically, the very outcome that President Erdoğan has tried to avoid by amending the Constitution, namely incongruence between the executive and legislative branches, may materialise under the new system. This 'cohabitation' scenario would most likely generate a gridlock in parliament and could even trigger a constitutional crisis between the president (provided that Erdoğan wins the 2019 presidential election) and the parliament, as recently seen in Venezuela. To avert this outcome, the AKP may resort to a new electoral system that favours the incumbent party at the expense of the opposition.

Erdoğan orchestrated the constitutional amendments to end political uncertainty by taking over the reins of the ruling party while still president. The 'executive' presidential model has given Erdoğan this opportunity. However, the narrow victory for the 'Yes' side indicated that consolidating and unifying the nationalist and conservative voters will be harder than Erdoğan expected. His overtures to Bahçeli did not lead him to win over the majority of the MHP voters, while still costing him Kurdish votes. Furthermore, Erdoğan's efforts to monopolise power and to limit dissent pushed opposition figures to act in concert during the referendum campaign. Subsequently, Kılıçdaroğlu's'Justice Walk' from Ankara to İstanbul to protest the conviction and arrest of a CHP MP was supported by a wide array of political parties and groups such as the HDP, MHP dissidents, and ÖDP (Özgürlük ve Dayanışma Partisi - Freedom and Solidarity Party) along with civil society organisations and professional associations like DiSK (Devrimci İşçi Sendikaları Konfederasyonu - the Confederation of Progressive Trade Unions of Turkey), KESK (Kamu Emekçileri Sendikaları Konfederasyonu - the Confederation of Public Sector Trade Unions) and TMMOB (Türk Mühendis ve Mimar Odaları Birliği - the Union of Chambers of Turkish Engineers and Architects), among others. Nearly half of the electorate voted against the constitutional amendments establishing Erdoğan's personal rule. Although they hail from different ideological backgrounds, opposition to the new regime could bring this heterodox group of voters together behind a popular candidate against Erdoğan, especially in the second round of the 2019 presidential election. While still unlikely, this scenario cannot be ruled out completely in the aftermath of the referendum. 
The AKP will therefore need to prevent the consolidation of the opposition bloc by neutralising or appeasing political elites who might throw in their lot with the official opposition CHP. In the coming year, the government needs to improve its economic performance to minimise any potential conflicts within its popular base and win the local, parliamentary, and presidential elections-all scheduled for 2019. The ruling AKP is still the favourite in these elections but faces growing risks as Erdoğan tries to monopolise power. His quest to remain in office against growing societal opposition may plunge Turkey into a deeper form of authoritarianism characterised by harsher constraints on civil liberties, a crackdown on opposition politicians and the media, and wider use of state coercion against anti-government protestors.

\section{Notes}

1. For more on polarisation, see Aydın-Düzgit \& Balta 2017

2. In 2014, the BDP merged with the HDP.

3. The first four articles of the 1982 Constitution define the Turkish state as a secular democratic republic based on the rule of law and Ataturk's nationalism, and designates Turkish as its official language and Ankara as its capital.

4. For the full text of the amendments, see https://www.trtworld.com/referendum/18-ways-theturkish-constitution-might-change-334921

5. As a counter-measure, a CHP MP broadcast the parliamentary talks via internet, reaching only internet savvy citizens (Habertürk 2017a).

6. The BBP received 0.6 percent of the votes in the November 2015 elections. Hüda-Par had nine independent candidates in the June 2015 elections, receiving 68,000 votes in total and decided not to run in November 2015.

7. FETÖ (Fethullahçı Terör Örgütü - Fethullahist Terror Organisation) refers to the Hizmet movement of US-based preacher Fethullah Gülen, who is accused by Turkish authorities of orchestrating the coup attempt in July 2016. DHKP-C (Devrimci Halk Kurtuluş Partisi/Cephesi - Revolutionary People's Liberation Party/Front) is a radical left wing organisation. The PKK (Partiya Karkaren Kurdistan - Kurdistan Workers Party), founded by Abdullah Öcalan in 1978, has launched an insurgency against the Turkish state in 1984 and the conflict, committing more than 30,000 lives, is yet to be resolved.

8. For an example see Kayadibi 2017.

9. The BBP leader's decision to support the 'Yes' side met with resistance among the party ranks and led to open revolt in the party's (only) electoral stronghold, Sivas province (Hürriyet 2017d).

10. The SP won 0.7 per cent of the vote in November 2015.

11. For more on the MHP see Aytürk 2014, Önis 2003.

12. For a short interview with Akşener on her campaign strategy, see https://www.youtube.com/ watch? $v=r N B Y k b 6 h t t Q \& t=2072 s$

13. On the party's historical roots, see Aytürk 2014.

14. The YSK issued 580 fines, mostly to pro-AKP media, for not giving enough airspace to the opposition in the November 2015 elections. (Resmi Gazete 2017).

15. In September 2010, the AKP called a national referendum on a series of constitutional amendments, presented as part of a single package. While some of its provisions expanded individual rights and associational liberties, others allowed the ruling party to change the composition of the Constitutional Court and the board that oversee judicial appointments. These changes subsequently undermined the rule of law, eroded the system of checks and balances, and skewed the political playing field in favour of the AKP. For more on the 2010 referendum, see Ciddi 2011 and Kalaycıoğlu 2012.

16. Elections under authoritarian regimes are considered as a tipping game in which citizens become more likely to vote for a candidate if they think that others will act in a similar fashion (Van de Walle cited in Gandhi \& Lust-Okar 2009). 


\section{Acknowledgements}

The authors would like to thank Gülnur Kocapınar and Hazan Sucu for their research assistance in the preparation of this paper, and two anonymous referees for their valuable comments on earlier drafts.

\section{Disclosure statement}

No potential conflict of interest was reported by the authors.

\section{Notes on contributors}

Berk Esen is assistant professor of international relations at Bilkent University. Before joining Bilkent, he received his PhD in Government from Cornell University. His research focuses on the political economy of development, democratisation, and political parties, with a regional focus on Latin America and the Middle East. His solo and co-authored articles have appeared in Journal of Democracy, Third World Quarterly, and Turkish Studies.

Şebnem Gümüş̧̧ü is assistant professor of political science at Middlebury College and the co-author (with E. Fuat Keyman) of Democracy, Identity, and Foreign Policy in Turkey: Hegemony Through Transformation (2014). Her research on political Islam, dominant parties, and democratic erosion has appeared in various journals including Comparative Political Studies, Journal of Democracy, Third World Quarterly, and Government and Opposition.

\section{References}

AHaber (2017) 'Erdoğan'dan torununa Kuran dersi' [Erdoğan teaches Qur'an to his grandson], 8 April, available online at: https://www.ahaber.com.tr/gundem/2017/04/08/erdogandan-torununa-kurandersi

AKP (2017) 'Türkiye Nisan Bülteni' [Turkey April Bulletin], available online at: https://www.akparti.org. tr/turkiyebulteni107/

Aljazeera (2017) 'Erdoğan: Evet kutlu yolculuğa onay' [Erdoğan:'Yes' is approval of the sacred journey], 7 February, available online at: https://aljazeera.com.tr/haber/erdogan-evet-kutlu-yolculuga-onay

Almonitor (2017) 'Erdoğan uses mosques to win referendum', 12 April, available online at: https://www. al-monitor.com/pulse/originals/2017/04/turkey-erdogan-uses-mosques-to-win-referendum.html

Aydın A. \& Emrence, C. (2016) 'Politics of confinement, curfews and civilian control in Turkish counterinsurgency', POMEPS, available online at: https://pomeps.org/2016/11/14/politics-ofconfinement-curfews-and-civilian-control-in-turkish-counterinsurgency/

Aydın-Düzgit S. \& Balta, E. (2017) 'Turkey after the July 15th coup attempt: when elites polarize over polarisation', Istanbul Policy Centre Report, available online at: https://ipc.sabanciuniv.edu/wpcontent/uploads/2017/04/Turkey-after-the-July-15-Coup-Attempt_Senem-Aydin-Duzgit_EvrenBalta.pdf

Aytaç, S. E., Çarkoğlu, A. \& Yıldırım, K. (2017) 'Taking sides: determinants of support for a presidential system in Turkey', South European Society and Politics, vol. 22, no. 1, pp. 1-20.

Aytürk, I. (2014) 'Nationalism and Islam in Cold War Turkey, 1944-69', Middle Eastern Studies, vol. 50, no. 5, pp. 693-719.

BBC Türkçe (2016) 'Anayasa uzlaşma komisyonu dağıldı' [Constitutional commission terminated], 17 February, available online at https://www.bbc.com/turkce/haberler/2016/02/160216_anayasa_ komisyonu

BBC Türkçe (2017) 'MHP'de üç milletvekili ve genel başkan adayı Oğan ihraç edildi' [Three MPs and Party Chairman Nominee Ogan are Expelled from the MHP], available online at: http://www.bbc. com/turkce/haberler-turkiye-39230566 (accessed 10 March). 
Birgün (2017) 'Bahçeli ilk evet mitingini yaptı' [Bahçeli held his first'yes' rally], 18 March, available online at: https://www.birgun.net/haber-detay/bahceli-ilk-evet-mitingini-yapti-tek-adam-diyenler-tarihcahili-151551.html

Çakır, R. (2017) ‘Tüm yönleriyle referandum' [The referendum with all its aspects...] 17 April, available online at: https://www.youtube.com/watch?v=3eG7oPQovUQ\&t=339s

Çarkoğlu, A. (2007) 'A new electoral victory for the 'pro-Islamists' or the 'new centre-right'? The Justice and Development Party phenomenon in the July 2007 parliamentary elections in Turkey', South European Society \& Politics, vol. 1, no. 4, pp. 501-519.

Çarkoğlu, A. (2008) 'Ideology or economic pragmatism?: Profiling Turkish voters in 2007', Turkish Studies, vol. 9, no. 2, pp. 317-344.

Ciddi, S. (2011) 'Turkey's September 12, 2010 referendum', MERIA Journal, vol. 15, no. 4.

CNNTürk (2017) 'YSK açıkladı: Mühürsüz oylar da sayılacak' [YSK announced: Unstamped ballots will be valid], 16 April, available online at: https://www.cnnturk.com/turkiye/son-dakika-ysk-acikladimuhursuz-oylar-da-sayilacak

Cumhuriyet (2017a) 'AKP'liler açık oy kullandı ortalık karıştı' [The AKP MPs casted open votes, stirring the parliament], 22 May, available online at: https://www.cumhuriyet.com.tr/video/video/657859/ AKP_liler_acik_oy_kullandi_ortalik_karisti..._Saglik_Bakani_Akdag_Sana_mi_soracagim_lan_. html

Cumhuriyet (2017b) 'Bakan Çelik: Hollanda'nın tavrı kararsızları netleştirdi' [Minister Çelik: the Dutch attitude convinced the undecided voters], 12 March, available online at: https://www.cumhuriyet. com.tr/haber/siyaset/696775/Bakan_Celik_Hollanda_nin_tavri_kararsizlari_netlestirdi_.html

Cumhuriyet (2017c) 'Hayır korkusu Denizli'de MHP'li muhaliflere verilen salonu iptal ettirdi' [Fear of no shuts down conference halls for MHP opposition in Denizli], 19 February, available online at: https://www.cumhuriyet.com.tr/haber/turkiye/679346/_Hayir_korkusu..._Denizli_de_MHP_li_ muhaliflere_verilen_salon_iptal_edildi.html\#

Cumhuriyet (2017d) 'HDP'nin sandık başkanları tek tek iptal ediliyor' [The HDP's ballot box commission heads are taken out of the lists], 25 March, available online at: https://www.cumhuriyet.com.tr/haber/ siyaset/706950/HDP_nin_sandik_baskanliklari_tek_tek_iptal_ediliyor.html

Dunham, M. \& Hintz, L. (2017) 'Turkey's president Erdoğan has gone to extremes to win Sunday's referendum. Here's why', available online at: https://www.washingtonpost.com/news/monkeycage/wp/2017/04/14/turkish-president-erdogan-resorted-to-unusual-tactics-before-sundaysreferendum-vote-heres-why/?utm_term=.17bb93cece16

Esen, B. \& Gümüş̧̧ü, Ş. (2016) 'Rising competitive authoritarianism in Turkey', Third World Quarterly, vol. 37, no. 9, pp. 1581-1606.

Esen, B. \& Gümüşçü, Ş. (2017) 'Turkey: how the coup failed', Journal of Democracy, vol. 28, no. 1, pp. $59-73$.

Gandhi, J. \& Lust-Okar, E. (2009) 'Elections under authoritarianism', Annual Review of Political Science, vol. 12, pp. 403-422.

Greene, K. (2007) Why Dominant Parties Lose: Mexico's Democratisation in Comparative Perspective, Cambridge University Press, New York, NY.

Habertürk (2017a) 'Ali Şeker Vekil TV ile 55 saat yayın yaptı [Ali Şeker aired for 55 hours in his MPTV], 14 January, available online at: https://www.haberturk.com/gundem/haber/1350497-ali-seker-vekiltv-ile-55-saat-canli-yayin-yapti

Habertürk (2017b) 'Nurettin Canikli: piyasalara yönelik bir atak söz konusu' [Nurettin Canikli: there is an attacks against the markets], 23 February, available online at: https://www.haberturk.com/gundem/ haber/1401723-nurettin-canikli-piyasalara-yonelik-bir-atak-soz-konusu

HDP (2017) 'Referandum 2017' [Referendum 2017], available online at: https://www.hdp.org.tr/tr/ materyaller/referandum-2017/10062

Henley, J. (2017) 'Recep Tayyip Erdoğan: we know Dutch from the Srebrenica massacre', 14 March, available online at: https://www.theguardian.com/world/2017/mar/14/turkish-sanctions-bizarreas-netherlands-has-more-to-be-angry-about-dutch-pm

Hürriyet (2017a) 'Erdoğan'dan hayır yorumu: Şerre rıza şerdir' [Erdoğan on the referendum: Consent for evil is evil], 18 February, available online at: https://www.hurriyet.com.tr/erdogandan-hayir-yorumuserre-riza-40369491 
Hürriyet (2017b) 'Erdoğan: Evet diyen ne kadar saygınsa hayır diyen de...' [Erdoğan: those who say no are equally respectable as those who say yes], 2 April, available online at: https://www.hurriyet.com. tr/erdogan-bu-millet-penaltiyi-iyi-atar-40414711

Hürriyet (2017c) 'Karamollaoğlu'ndan cumhurbaşkanlığı hükümet sistemi eleştirisi' [Karamollaoğlu's critique of the presidential system], 19 February, available online at: https://www.hurriyet.com.tr/ karamollaoglundan-cumhurbaskanligi-hukumet-sistemi-elestirisi-40370372

Hürriyet (2017d) 'BBP'de Sivas Krizi' [Sivas crisis in the BBP], 11 March, available online at: https://www. hurriyet.com.tr/bbpde-sivas-krizi-40392041

Kalaycıoğlu, E. (2010) Justice and Development Party at the helm: Resurgence of Islam or restitution of the right of centre predominant party?', Turkish Studies, vol. 11, no. 1, pp. 29-44.

Kalaycıoğlu, E. (2012) 'Kulturkampf in Turkey: the constitutional referendum of 12 September 2010', South European Society and Politics, vol. 17, no. 1, pp. 1-22.

Kalaycıoğlu, E. (2017) 'Two elections and a political regime in crisis: Turkish politics at the crossroads', Southeast European and Black Sea Studies, available online at: 10.1080/14683857.2017.1379148.

Karaman, H. (2017) 'Neyi Oyluyoruz' [What are we voting for?], 13 April, available online at: https:// www.yenisafak.com/yazarlar/hayrettinkaraman/neyi-oyluyoruz-2037309

Kayadibi, S. (2017) 'Referandum degil bu vatan mudafası' [This is not a referendum, it is defense of the homeland], 6 April, available online at: https://www.milatgazetesi.com/referandum-degil-buvatan-mudafasi-makale-110574

Kemahlıoğlu, Ö. (2015) 'Winds of change? The June 2015 parliamentary election in Turkey', South European Society and Politics, vol. 20, no. 4, pp. 445-464.

KONDA (2017) 16 Nisan Halkoylaması Sandık ve Seçmen Analiz Raporu. Konda, Istanbul.

Magaloni, B. (2006) Voting For Autocracy, Cambridge University Press, New York, NY.

Milliyet (2017) 'Cumhurbaşkanı yardımcısı olmam yakışık almaz' [It would be inappropriate for me to be vice-president], 20 March, available online at: https://www.milliyet.com.tr/-cumhurbaskaniyardimcisi-olmam-siyaset-2416703/

New York Times (2017) 'Turkey referendum is haunted by allegations of voter fraud', 18 April, available online at: https://www.nytimes.com/2017/04/18/world/europe/turkey-referendum-is-haunted-byallegations-of-voter-fraud.html?_r=0

NTV (2017) ‘Başbakan Yıldııım: PKK, FETÖ, HDP hayır dediği için evet diyoruz' [PM Yıldııım: We say yes because the PKK, FETÖ and HDP says no], 5 February, available online at: https://www.ntv.com.tr/ turkiye/basbakan-yildirim-pkk-feto-hdp-hayir-dedigi-icin-evet-diyoruz,CgyPjoMkGEOGlqU4ajUpgg

Önis, Z. (2003) 'Globalisation, democratisation and the far right: Turkey's nationalist action party in critical perspective', Democratisation, vol. 10, no. 1, pp. 27-52.

Öniş, Z. (2016) ‘Turkey's two Elections: The AKP comes back', Journal of Democracy, vol. 27, no. 2, pp. 141-154.

OSCE (2017) 'Constitutional Referendum, 16 April 2017', available online at: https://www.osce.org/ odihr/elections/turkey/303681

Özbudun, E. (2015) 'Turkey's judiciary and the drift toward competitive authoritarianism', The International Spectator, vol. 50, no. 2, pp. 42-55.

Posta (2017) 'Meral Akşener'in Kocaeli'ndeki toplantısına saldırı' [Attack on Meral Akşener's meeting in Kocaeli], 18 March, available online at: https://www.posta.com.tr/meral-aksener-in-kocaeli-ndekitoplantisina-saldiri-haberi-1278377

Resmi Gazete (2017) ‘Kanun Hükmünde Kararname 687' [Decree no 687], 9 February, available online at: https://www.resmigazete.gov.tr/eskiler/2017/02/20170209-8.htm

Sabah (2017) 'Başbakan referandumda kaç ile gidecek?' [How many cities would the PM visit in the referendum campaign?], 26 February, available online at: https://www.sabah.com.tr/ gundem/2017/02/26/basbakan-referandumda-evet-icin-kac-ile-gidecek

Sayarı, S. (2016a) 'Back to a predominant party system: the November 2015 snap election in Turkey', South European Society and Politics, vol. 21, no. 2, pp. 263-280.

Sayarı, S. (2016b) 'Opposition parties and democratic consolidation in Turkey', in Democratic Consolidation in Turkey: Micro and Macro Challenges, ed. Paul Kubicek and Cengiz Erişen, Routledge, London, pp. 166-183. 
'Seçim Kanunu' [Electoral Law] (1961) Available online at: http://www.mevzuat.gov.tr/MevzuatMetin/ 1.4.298.pdf

Somer, M. (2016) 'Understanding Turkey's democratic breakdown: old versus new and indigenous versus global authoritarianism', Southeast European and Black Sea Studies, vol. 16, no. 4, pp. 481-503.

T24 (2017a) 'Erdoğan: Cumhurbaşkanlığı sistemi olsaydı iki kat daha zengin olacaktık' [We would have been twice as rich if we had a presidential system], March 11, available online at: https://t24.com.tr/ haber/erdogan-cumhurbaskanligi-sistemi-olsaydi-iki-kat-daha-zengin-olacaktik,393145

T24 (2017b) 'Adalet Bakanı Bekir Bozdağ: Terör örgütleri hayır için çalışıyor' [Terrorists are working for' ${ }^{N o}$ ' vote], 4 February, available online at: https://m.t24.com.tr/amp/haber/adalet-bakani-bekirbozdag-teror-orgutleri-hayir-icin-calisiyor,387009

T24 (2017c) 'Erdoğan: 15 Temmuz'da milletimin üzerine bomba yağdıranlar bugünün hayırcıları' [Erdoğan: Those who bombed my people on July 15th are today's naysayers], 5 March, available online at: https://t24.com.tr/haber/erdogan-15-temmuzda-milletimin-uzerine-bomba-yagdiranlarbugunun-hayircilaridir,392106

T24 (2017d) 'Cumhurbaşkanı: Böyle bir sisteme evet denmez de ne denir' [The president: how can one not say yes to this system], 11 February, available online at: https://t24.com.tr/haber/cumhurbaskaniboyle-bir-sisteme-evet-denmez-de-ne-denir-elbette-evet-diyoruz,388255

T24 (2017e) 'Bakanların katılacağı etkinlikler hangi ülkelerde neden iptal edildi?' [Why and which countries cancelled ministers' events?],11 March, available online at: https://t24.com.tr/haber/ bakanlarin-katilacagi-etkinlikler-hangi-ulkelerde-neden-iptal-edildi,393142

T24 (2017f) 'Hollanda'dan sınır dışı edilen Bakan Kaya: OHAL'i sorgulayan batı bir gecede OHAL ilan etti' [Minister Kaya expelled from the Netherlands: the West critical of the emergency rule announced emergency rule overnight], 12 March, available online at: https://t24.com.tr/haber/hollandadansinir-disi-edilen-bakan-kaya-ohali-sorgulayan-bati-bir-gecede-ohal-ilan-etti,393235

T24 (2017g) 'Akşener'in Çanakkale programında otel elektriği kesti, polis salonu bastı' [Akşener's meeting in Çanakkale: The hotel managers cut the electricity; the police raids the meeting], 11 February, available online at: https://t24.com.tr/haber/aksenerin-canakkale-programinda-otelelektrigi-kesti-polis-salonu-basti,388263

Yeniçağ (2017a) 'Türk milliyetçileri hayır diyor platformu Ankara'da buluşuyor' ['Turkish nationalists says no' platform convenes in Ankara], 13 February, available online at: https://www.yenicaggazetesi. com.tr/turk-milliyetcileri-hayir-diyor-platformu-ankarada-bulusuyor-156948 h.htm

Yeniçağ (2017b) 'Niğde Valiliği Akşener'in programını iptal etti' [Niğde provincial governor cancels Akşener's meetings], 16 March, available online at: https://www.yenicaggazetesi.com.tr/nigdevaliligi-aksenerin-programini-iptal-etti-159286 h.htm

Yeniçağ (2017c) 'Erdoğan: Dünyanızı da ahiretinizi de tehlikeye atmayın' [Erdoğan to naysayers: 'Do not risk your life and afterlife'], 5 April, available online at: https://www.yenicaggazetesi.com.tr/ erdogan-dunyanizi-da-ahiretinizi-de-tehlikeye-atmayin-1597v.htm

Yurt (2017) 'Meral Akşener: Bahçeli koltuk için evet diyor' [Meral Akşener: Bahçeli says yes to preserve his leadership], 24 February, https://www.yurtgazetesi.com.tr/politika/meral-aksener-bahceli-koltukicin-evet-diyor-h23566.html 